\title{
微粉炭燃焼場におけるすす計測技術
}

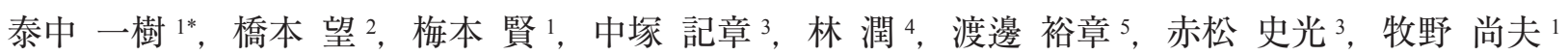

\section{Measurement Techniques for Soot in Pulverized Coal Combustion Fields}

\author{
Kazuki Tainaka $^{{ }^{*}}$, Nozomu Hashimoto ${ }^{2}$, Satoshi Umemoto ${ }^{1}$, Noriaki Nakatsuka ${ }^{3}$, Jun Hayashi ${ }^{4}$, Hiroaki Watanabe ${ }^{5}$, \\ Fumiteru Akamatsu ${ }^{3}$ and Hisao Makino ${ }^{1}$
}

\begin{abstract}
In this paper, results of experiments that authors carried out to investigate soot formation in pulverized coal combustion fields were summarized. Soot particles form at the local spatial and temporal scales. Hence, laser induced incandescence (LII), which has high spatial and temporal resolution, was applied to the measurement of soot volume fraction. Firstly, details of LII in the present study is described. Secondly, soot formation from pulverized coal were measured by LII measurement and simultaneous measurements of Mie scattering and Laser induced fluorescence (LIF). Finally, soot growth, agglomeration, and oxidation processes were investigated through Time-Resolved LII (TiRe-LII).
\end{abstract}

Keywords: Pulverized coal combustion, Soot, Laser induced incandescence (LII), Laser induced fluorescence (LIF), Time-resolved laser induced incandescence (TiRe-LII).

\section{1. 緒言}

石炭は, 火力発電に使用されているほかの化石燃料と 比べて, 発熱量あたりの単価が安く, 埋蔵量が豊富であ り，世界に広く分布していることから，電力の安定供給 に欠かすことのできない重要なエネルギー源の一つであ る。

石炭火力発電では, 石炭の比表面積を増やし燃焼効率 を向上させるために, 体積中位径 $40 \mu \mathrm{m}$ 程度まで粉砕す る微粉炭燃焼方式を用いることが一般的である。微粉炭 燃焼場では，空気搬送された微粉炭粒子が，火炎からの

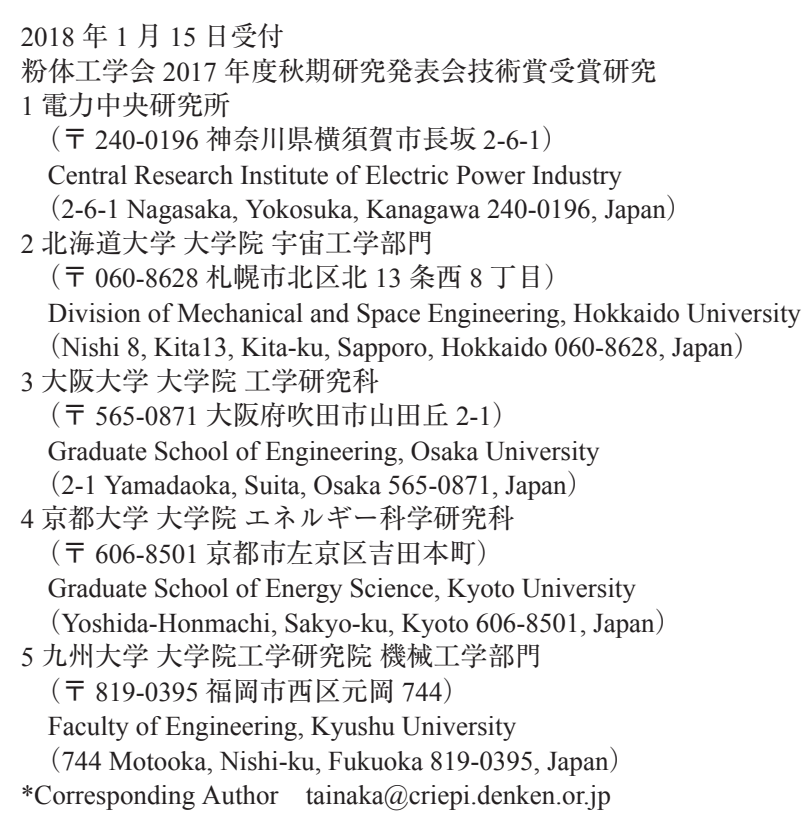

ふく射および高温の気体からの熱伝達によって加熱され 揮発分を放出し，その揮発分と固定炭素分がそれぞれ燃 焼している。これらの素過程は，互いに影響をおよぼし ながら同時に進行するため, 微粉炭燃焼現象をさらに複 雑にしている。

筆者らは, 微粉炭然焼現象の解明を目指して, さまざ まな研究を行ってきた[1-5]。本稿では, それらの中か ら, すす生成過程の解明を目指した研究とその成果 $[4,5]$ を紹介する。すすは, 揮発分が気相反応で重合すること で生じる粒子状の固体であり, $\mathrm{PM}_{2.5}$ の原因の一つでもあ る環境負荷物質である。一方で, ふく射を介した熱輸送 によってボイラへの伝熱や微粉炭粒子の着火, 燃え切り に対して，影響をおよぼす物質でもある。そのため，す す生成過程の解明とその知見に基づくすす生成の制御技 術が求められる。従来, すすに対してよく用いられてい るプローブによるサンプリング計測といった接触計測で は, 計測器が流れ場を乱すだけでなく, 接触部分への微 粉炭粒子やすすの付着によって, 高精度に現象を把握す ることは困難である。加えて, すすの生成は時間的・空 間的に局所で生成されるため, 高い時間分解能が必要と なる。そこで, 筆者らは, 微粉炭燃焼場に適した非接触 すす体積分率計測技術を新たに確立した。本稿では，非 接触すす体積分率計測技術の開発と, その技術をすす生 成特性の解明に応用した結果を紹介する。

\section{2. 実験方法}

\section{1 実験装置}

Fig. 1 に, 微粉炭ジェットバーナ実験装置の概略図を 示す。本装置は, 気体燃料を保炎用に用いて, 微粉炭乱 


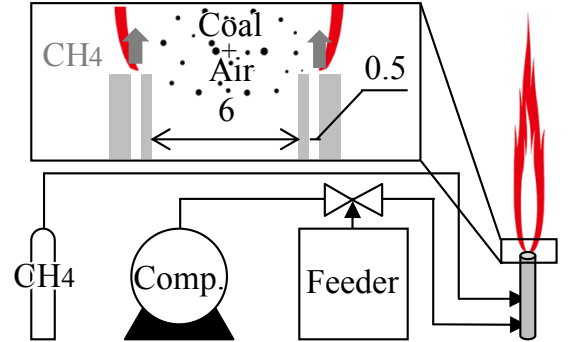

Fig. 1 Schematic diagram of the pulverized coal jet burner and the supply system

Table 1 Properties of coal

\begin{tabular}{lllc}
\hline Proximate analysis & Volatile matter & {$[\mathrm{mass} \% \mathrm{db}]$} & 26.9 \\
& Fixed carbon & {$[\mathrm{mass} \% \mathrm{db}]$} & 57.9 \\
& Ash & {$[\mathrm{mass} \% \mathrm{db}]$} & 15.2 \\
\hline Ultimate Analysis & Carbon & {$[\mathrm{mass} \% \mathrm{db}]$} & 71.9 \\
& Hydrogen & {$[\mathrm{mass} \% \mathrm{db}]$} & 4.4 \\
& Oxygen & {$[\mathrm{mass} \% \mathrm{db}]$} & 6.5 \\
& Nitrogen & {$[\mathrm{mass} \% \mathrm{db}]$} & 1.5 \\
& Sulfur & {$[\mathrm{mass} \% \mathrm{db}]$} & 0.4 \\
\hline Moisture & & {$[\mathrm{mass} \%]$} & 2.6 \\
\hline Lower heating value & & {$[\mathrm{MJ} / \mathrm{kg}]$} & 28.1 \\
\hline
\end{tabular}

$\mathrm{db}$ : dry basis

流火炎を形成する装置である。おもに，コンプレッサ， マスフローコントローラ, スクリューフィーダ, バーナ, および排ガス処理系で構成されている。

バーナは, 内径 $6.0 \mathrm{~mm}$ の主流流路と保炎用スリット

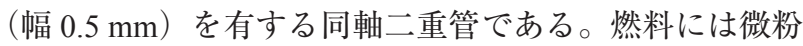
炭, 酸化剤には空気を使用する。空気は除湿フィルタお よび除じんフィルタを通った後, コンプレッサからマス フローコントローラを用いて定量供給され，微粉炭は空 気流路に設置されたエジェクタにスクリューフィーダを 用いて定量供給される。微粉炭と空気の混合気は，主流 流路から鉛直上向きに噴出される。保炎用の気体燃料に はメタン $\left(\mathrm{CH}_{4}\right)$ を使用し, ボンベからマスフローコン トローラを用いて，保炎用スリットに定量供給される。 燃焼後の排ガスは, バグフィルタで除じんされた後, ファ ンによって大気に放出される。

\section{2 実験条件}

燃料にはニューランズ炭 (豪州歴青炭), 酸化剤には空 気，保炎用燃料にはメタンを用いた。Table 1, Fig. 2 に, 使用したニューランズ炭の性状および粒子径分布をそれ ぞれ示す。微粉炭の体積中位径は $53.7 \mu \mathrm{m}$ で, 200 メッ シュパス $80 \%$ 以上の実際の発電所で使用されている粒子 径分布に近いものを用いた。Table 2 に, 実験条件を示 す。保炎用燃料であるメタンの供給量は，メ夕ン燃焼が 微粉炭火炎におよぼす影響を極力抑えるために，火炎が 安定的に形成される範囲で最低の供給量とした。形成さ れる火炎の長さは, 時間的な変動はあるが, およそ $350 \mathrm{~mm}$ である。

\section{3. すす体積分率計測技術の選定と最適化[4]}

すすは局所的な反応で生成されるため，その現象解明

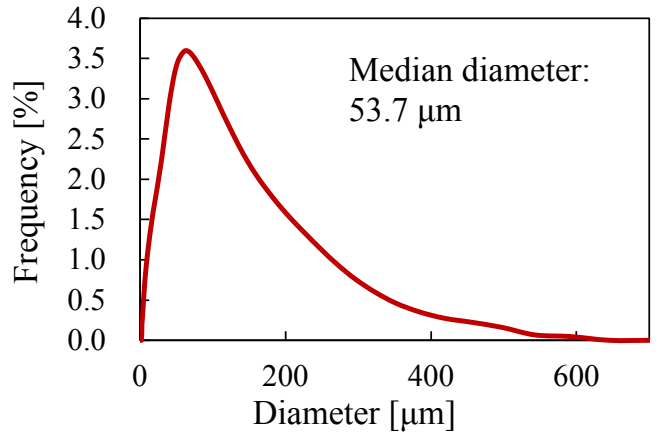

Fig. 2 Particle-size distribution of coal

Table 2 Experimental condition

\begin{tabular}{llc}
\hline Coal feed rate & {$[\mathrm{g} / \mathrm{h}]$} & 536.4 \\
Air flow rate & {$\left[\mathrm{L}_{\mathrm{N}} / \mathrm{min}\right] @ 20^{\circ} \mathrm{C}$} & 10.8 \\
$\mathrm{CH}_{4}$ flow rate & {$\left[\mathrm{L}_{\mathrm{N}} / \mathrm{min}\right] @ 20^{\circ} \mathrm{C}$} & 1.4 \\
\hline Coal heat input & {$[\mathrm{kW}] @ \mathrm{LHV}$} & 4.19 \\
$\mathrm{CH}_{4}$ heat input & {$[\mathrm{kW}] @ \mathrm{LHV}$} & 0.83 \\
\hline Reynolds number (only center flow) & {$[-]$} & 2544 \\
Equivalence ratio (only coal) & {$[-]$} & 6.09 \\
\hline
\end{tabular}

には, 高い時空間分解能の計測技術が要求される。そこ で, すす体積分率計測に, ナノ秒オーダの高い時間分解 能を持ち, レーザシート内の 2 次元分布を一度に取得可 能なレーザ誘起赤熱法（LII： Laser Induced Incandescence）を選定した。LII 計測は, レーザ照射で加 熱されたすすからの赤熱光強度（LII 信号強度）がすす 体積分率にほほ比例する性質から, すす体積分率を計測 する手法である。その計測原理は, Melton が行った理論 解析の結果[6]を基としている。

Meltonは，おもに以下の仮定を用いて，1つのすす粒 子のふく射強度から, 計測箇所に存在するすべてのすす 粒子に対して積分することで, LII 信号強度の式である Eq. (1) を得た。

・すす粒子のふく射強度は, プランクの法則および Mie 理論の吸収係数に従う。

・すすの粒子径が光の吸収長さより小さい。

・レーザによる入熱が，すべてすすの昇華熱となる。

・すすはレーザ加熱によって昇華温度となっており， 温度の時間変化はない。

$$
J=C_{1} \int_{0}^{\infty} a^{3+\frac{1.54 \times 10^{-7}}{\lambda}} N p(a) d a
$$

ここで， $C_{1}$ は定数， $J$ は LII 信号強度[W], $a$ はすす粒子 の半径 $[\mathrm{m}], \lambda$ はレーザ波長および検出波長 $[\mathrm{m}], N$ はすす 粒子数, $p(a)$ は粒子径分布を示す。Eq. (1)より, $\lambda$ の值が 可視光の波長域である $400 \mathrm{~nm}$ から $700 \mathrm{~nm}$ の間にある場 合, 信号強度はすす粒子径の 3.22 乗から 3.39 乗に比例 し，すす体積分率にほほ比例していることが分かる。LII 計測を, 気体燃料や液体燃料を用いた火炎に対して, 実 際に適用した研究は多くなされており[たとえば 7-16], ほかのすす体積分率計測技術と同様の結果を得ることが できたと報告されている[たとえば 7,9]。 


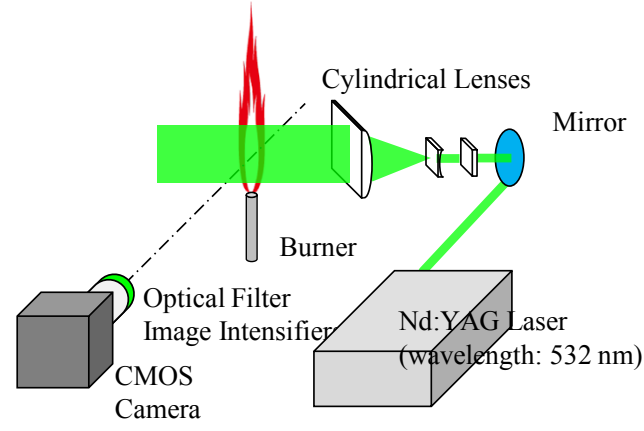

Fig. 3 Schematic diagram of LII measurement

燃燒場に LII 計測を適用する際, レーザエネルギー密 度はすすからの LII 信号強度に大きな影響をおよぼす。 $\mathrm{Ni}$ らは, エタンー空気層流拡散火炎を対象に, レーザエ ネルギー密度と固定した高さでの LII 信号強度半径方向 分布における最大值の関係を計測し，レーザエネルギー 密度の増加に応じて, LII 信号強度が増加し, レーザエ ネルギー密度が $0.27 \mathrm{~J} / \mathrm{cm}^{2}$ 以上に達すると, LII 信号強度 が減少していくことを明らかとした[8]。彼らは，この理 由として, Tait らの数值解析の結果[16]に基づいて, 高い レーザエネルギー密度によってすすが昇華し消滅したた めであると考察を行っている。以上のことから，レーザ エネルギー密度を高く設定すると，正確にすす体積分率 を計測することが難しい点に注意して計測を行う必要が ある。加えて, 微粉炭燃燒場では, 微粉炭粒子も赤熱し て LII 信号を発するため, 正確なすす体積分率を計測で きない愳念がある。そこで，微粉炭粒子の熱容量がすす 粒子の熱容量よりも大きいことから，すすのみが赤熱す るレーザエネルギー密度があるとの想定の下に，適切な 計測条件を検討した。

Fig. 3 に, LII 計測系の概略図を示す。光源には, Nd:YAG レーザの第 2 高調波（波長：532 nm）を使用し，シリン ドリカルレンズ群によって, シート光として火炎の中心 軸に照射した。信号強度の 2 次元分布の取得には, CMOS カメラ（Vision Research 社製，Phantom V5.0）を使用し

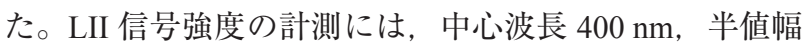
$60 \mathrm{~nm}$ のバンドパスフィルタを使用した。レーザ照射か ら計測までに $100 \mathrm{~ns}$ 遅れさせることで，レーザが揮発分 を励起し発生してしまう蛍光の影響を取り除いた。

Fig. 4 に，レーザシートのエネルギー密度分布を示す。 一般的にレーザ光はエネルギー密度分布を持っており, その影響を LII 信号強度も受ける。Fig. 4 (a)より，レー ザエネルギー密度は, 厚さ方向におよそ $0.1 \mathrm{~mm}$ のガウ シアン分布となっている。本研究では, レーザエネルギー 密度の高さ方向について，エネルギー密度が下がる領域 も含めて用いるガウシアンプロファイル（Fig. 4 (b)）と レーザシートの中でもエネルギー密度が一定の箇所に 絞って用いる均一プロファイル（Fig. 4 (c)）を対象に, レーザシートプロファイルによる影響を調べた。Fig. 5 に，バーナ先端から高さ $135 \mathrm{~mm}$ における，レーザエネ ルギー密度と燃焼場, 非燃焼場からの LII 信号強度の関

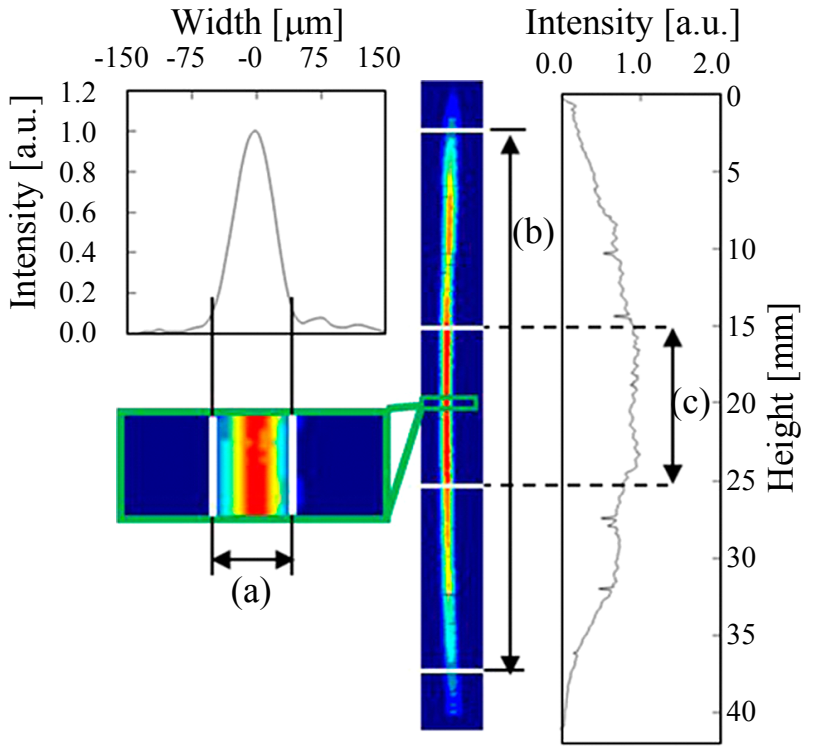

Fig. 4 Laser sheet profile; (a) Width of the laser sheet, (b) Height of the Gaussian laser sheet, (c) Height of the homogeneous laser sheet [4]

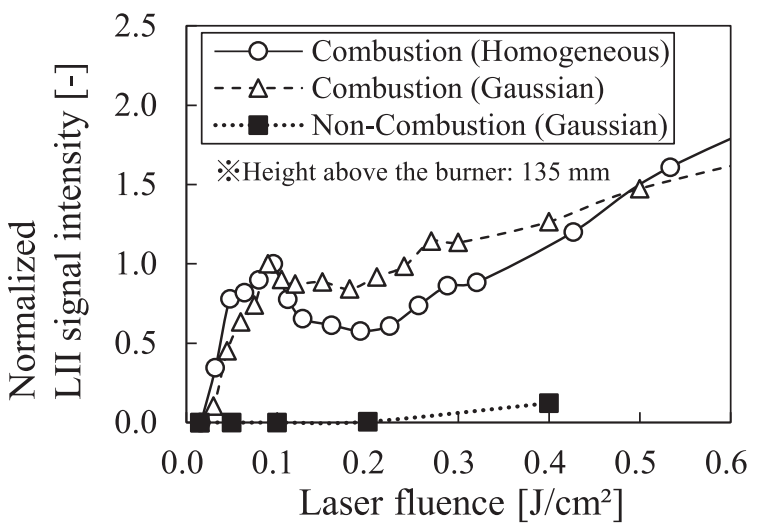

Fig. 5 LII signal intensity normalized by the value at $0.1 \mathrm{~J} / \mathrm{cm}^{2}$ (Gaussian) as a function of the laser fluence [4]

係を示す。Fig. 5 より，ガウシアンプロファイルおよび 均一プロファイルともに, 燃焼場ではレーザエネルギー 密度の上昇に伴って, LII 信号強度は上昇し，一度低下 した後, 再度上昇する。LII 信号強度の低下は, エネル ギー密度の増加によって，すす粒子が昇華したためであ ると考えられる。また, LII 信号強度の再上昇は, 非燃 焼場での LII 信号強度も上昇していることから, 微粉炭 からの LII 信号強度が重畳したためであると考えられる。 以上より, 昇華が生じず, LII 信号強度の大きい $0.1 \mathrm{~J} / \mathrm{cm}^{2}$ を用いることで, 微粉炭燃焼場に適用可能な LII 計測手 法を確立した。以降の節において，LII 計測には，この レーザエネルギー密度でガウシアンプロファイルのレー ザシートを用いた。

\section{4. 微粉炭粒子からのすす生成過程の解明[4]}

微粉炭粒子が高温場において揮発分を放出し，その揮 発分からすすが生成される過程を解明するために, 微粉 炭粒子，すすおよび高温場の 2 次元分布を計測した。粒 


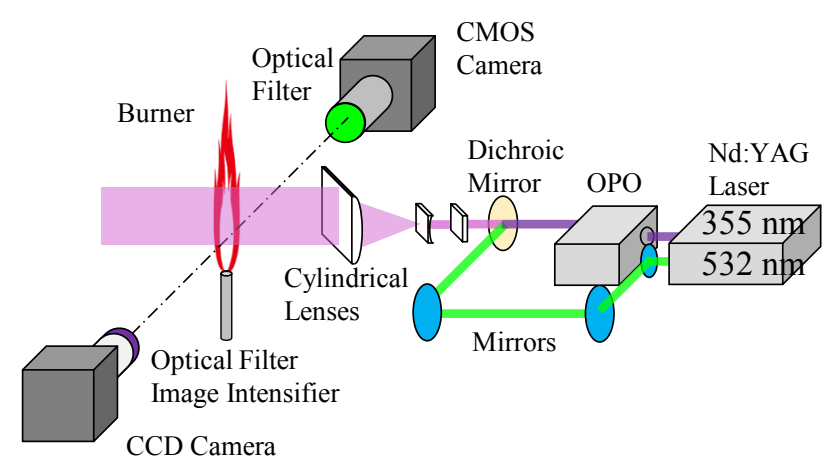

Fig. 6 Schematic diagram of simultaneous measurements of Mie scattering and $\mathrm{OH}-\mathrm{LIF}$

子表面でのレーザ散乱光である Mie 散乱を用いて微粉炭 粒子の 2 次元分布を, LII を用いてすすの 2 次元分布を, OH ラジカルヘのレーザ誘起蛍光法（LIF：Laser Induced Fluorescence）を用いて高温場の 2 次元分布を計測した。 LIF 計測は，化学種固有の励起しやすい波長のレーザを 照射することで, 特定の化学種を励起し, その発光強度 によって，分子の濃度や分布を計測する手法である。 $\mathrm{OH}$ ラジカルは，燃焼反応の中間生成物として生成される活 性化学種であり, 高温場においてほかの活性化学種と比 ベて多く存在する。

Fig. 6 に, Mie 散乱および OH-LIF 同時計測系の概略図 を示す。光源には, Nd:YAG レーザの第 2 高調波㧍よび 第 3 高調波, (波長 : $532,355 \mathrm{~nm}$ )を用いた。波長 $355 \mathrm{~nm}$ のレーザ光は, OPO (Optical Parametric Oscillation, SpectraPhysics 社製，MOPO-730）によって，OH ラジカルを励 起させるために波長 $285.586 \mathrm{~nm}$ に変換した。その後，名 イクロイックミラーによって, 波長 $532 \mathrm{~nm}$ のレーザ光 と合流し，シリンドリカルレンズ群によって， シート光 に成形され，バーナ中心軸へと入射される。信号強度の 2 次元分布の取得には, Mie 散乱計測用に CMOS カメラ (Vision Research 社製，Phantom V5)，OH-LIF 計測用にイ メージインテンシファイアおよびCCD カメラ（Roper 社 製，Model EEV 02-06-202）を使用し，火炎を挟んで対向 させることで同じ画角の画像を取得した。カメラ先端部 には，光学フィルタを設置した。光学フィルタは, Mie 散乱計測用に中心波長 $532 \mathrm{~nm}$, 半值幅 $1 \mathrm{~nm}$ のバンドパ スフィルタ, OH-LIF 計測用に中心波長 $320 \mathrm{~nm}$ ，半值幅 $20 \mathrm{~nm}$ のバンドパスフィルタを用いた。

Fig. 7 に, LII 計測および Mie 散乱-OH-LIF 同時計測の 結果を示す。2 次元分布は, バーナ先端から高さ 15 $45 \mathrm{~mm}, \quad 45 \sim 75 \mathrm{~mm}, \quad 75 \sim 105 \mathrm{~mm}, 105 \sim 135 \mathrm{~mm}, 135 \sim$ $165 \mathrm{~mm}, \quad 165 \sim 195 \mathrm{~mm}$ の結果を示す。Fig. 7 より, Mie 散乱光強度と OH-LIF 信号強度の 2 次元分布を比較する と，上流において微粉炭粒子群を囲むように高温領域が 分布し, バーナ先端からの高さの増加に伴って, バーナ 中心軸付近の微粉炭粒子群にも高温領域が現れる。これ は, 下流に行くにしたがって, 外周に存在する高温のメ タンの既燃ガスと微粉炭粒子の混合が進み, 高温場によっ て微粉炭粒子から揮発分が放出され，揮発分が燃焼した ためであると考えられる。LII 信号強度の 2 次元分布よ
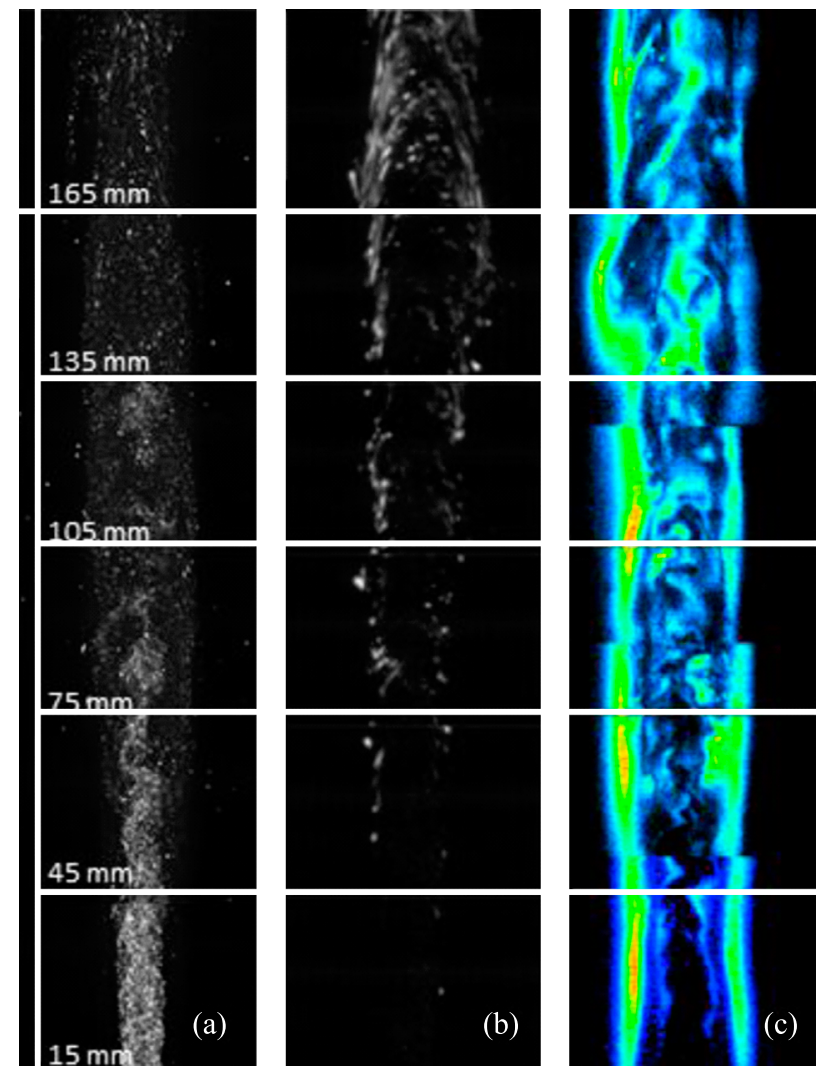

Fig. 7 Two-dimensional distributions of (a) Mie scattering, (b) LII, and (c) OH-LIF [4]

り，下流に行くにしたがって，すす体積分率が増加して いる。これは，下流において微粉炭粒子群に高温領域が 見られることから, 揮発分の放出が進むことで, 揮発分 の濃度が上昇しすす生成が活発に行われたためであると 考えられる。揮発分濃度だけでなく，すす生成には，揮 発分の体積分率だけでなく温度や酸素濃度といったほか の要因も影響をおよぼすことが推察される。本実験を対 象とした数值解析結果から, す寸体積分率の高い箇所で は, 温度が高く酸素濃度が低いという結果が示されてい る[17]。

\section{5. すすの成長, 凝集, 酸化過程の解明[6]}

すすの成長，凝集，酸化過程を解明するために，すす 粒子径計測が可能な時間分解 LII （TiRe-LII：TimeResolved LII）を適用した。TiRe-LII は，レーザ加熱後, 時間差をつけLII 信号強度計測を行う手法であり, 粒子 径が小さいほど比表面積が大きく放熱量が大きくなるた め, LII 信号強度 (赤熱光強度) の減衰も大きいという 性質を利用して，粒子径を算出する計測技術である。

Fig. 8 に, TiRe-LII 計測系の概略図を示す。光源には, $\mathrm{Nd}: Y A G$ レーザの第 2 高調波（波長： $532 \mathrm{~nm}$ ）を用いた。 発振されたレーザ光は, シリンドリカルレンズ群によっ て, シート光に成形され，バーナ中心軸へと入射される。 $1 / 2$ 波長板と偏光ビームスプリッタの使用により, レー ザエネルギー密度分布の形状を変化させずに, レーザシー ト光強度の調整を行えるようにした。LII 信号強度の 2 


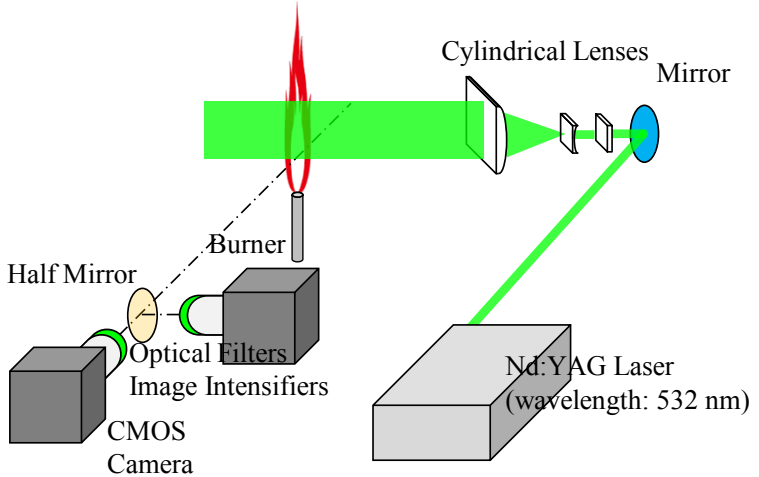

Fig. 8 Schematic diagram of TiRe-LII measurement

次元分布の取得には, 2 台の CMOS カメラ（Vision Research 社製，Phantom V12）を使用し，ハーフミラーに より同じ画角の画像を取得した。LII 信号以外の光を除 去するため, カメラ先端部には, イメージインテンシファ イア（I. I., 浜松ホトニクス社製，C9016-23MOD）および 光学フィルタを設置した。光学フィルタは, 中心波長 $400 \mathrm{~nm}$, 半值幅 $60 \mathrm{~nm}$ のバンドパスフィルタを用いた。 1 台目のカメラは, レーザ照射開始時刻より $100 \mathrm{~ns}$ 遅延 したタイミングから $20 \mathrm{~ns}$ 間撮影し, 2 台目のカメラは, レーザ照射開始時刻より $550 \mathrm{~ns}$ 遅延したタイミングから $20 \mathrm{~ns}$ 間撮影した。1 台目に対して 2 台目のカメラの撮影 タイミングを $450 \mathrm{~ns}$ 遅らせることにより, LII 信号強度 の減衰量を検知し, 粒子径分布に関する情報を取得した。

Fig. 9 に, 本研究で使用した熱泳動サンプリング（TS： Thermophoretic Sampling）システムの概略図を示す。す す粒子のサンプリングは, 透過型電子影微鏡（TEM： Transmission Electron Microscope）用のグリッドを火炎の 中に直接挿入し, 熱泳動原理により TEM グリッドの表

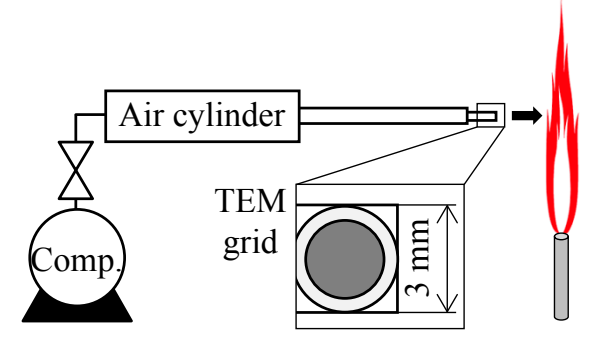

Fig. 9 Schematic diagram of TS system

面に堆積させることにより行った。熱泳動は, 温度勾配 のある場において粒子が非常に小さい場合に，粒子が高 温側の気体から受ける運動量が低温側の気体から受ける 運動量よりも十分に大きくなることで, 粒子が高温側か ら低温側に向けて力を受け移動する現象である。TS シス テムでは, 高温部は燃焼場, 低温部は TEM グリッドと して温度勾配を生じさせ，すす粒子を TEM グリッドに サンプリングする。TEM グリッドの火炎への挿入時間 は, 空気駆動シリンダとシーケンサを組み合わせたシス テムにより，160 ms に制御した。サンプリングされたす すは, 走查型電子顕微鏡 (SEM：Scanning Electron Microscope）を用いて撮影し，その SEM 画像から粒子径 分布を算出した。

Fig. 10 に，TS システムによるすす粒子径分布の計測 結果を示す。Fig. 10 (a), (b), および (c) は, 火炎の直接 撮影と LII 計測結果を重ね合わせた画像, TS システムで サンプリングしたすすの SEM 画像，およびSEM 画像か ら計測した体積基準のすすの粒子径累積分布をそれぞれ 示す。Fig. 9 (c) 中の実線は以下の式で示す対数正規累積 分布関数により計測結果を近似したものである。
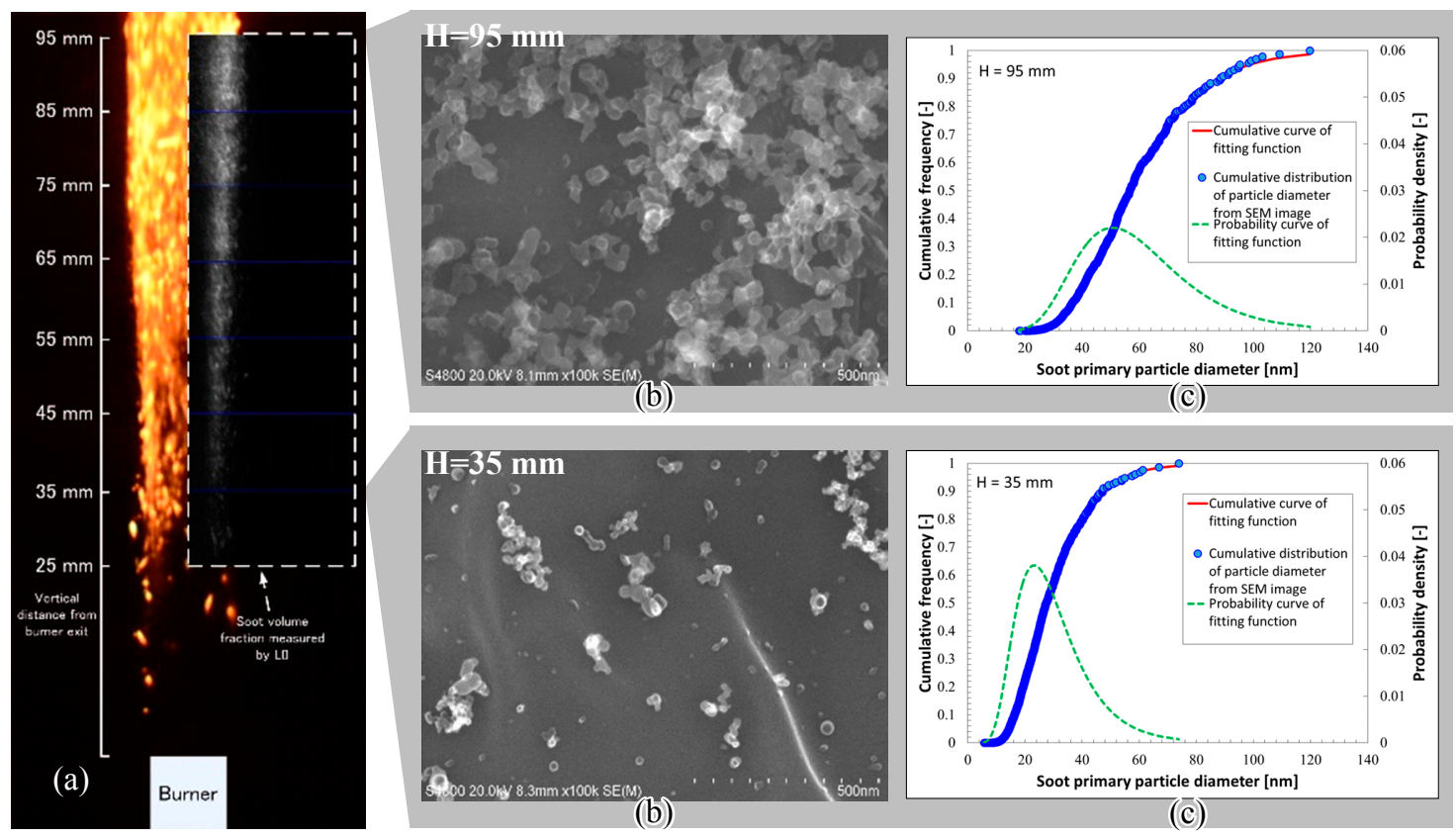

Fig. 10 Experimental results of TS system; (a) Direct photograph and results of LII, (b) SEM image, (c) Particle-size distribution of soot [5] 
Table 3 Fitting parameter of TiRe-LII measurement [5]

\begin{tabular}{cccc}
\hline $\mathrm{H}[\mathrm{mm}]$ & $\mathrm{k}_{1}$ & $\mathrm{k}_{2}$ & $\mathrm{k}_{3}$ \\
\hline 35 & 80.7 & 1.054 & 19.7 \\
95 & 118.6 & 0.996 & 40.9 \\
\hline
\end{tabular}

$$
F\left(D_{p}\right)=\Phi\left\{\frac{\ln \left(D_{p}\right)-\mu}{\sigma}\right\}
$$

ここで， $D_{p}$ はすす粒子径， $\Phi$ は標準正規分布の累積分布 関数， $\mu, \sigma$ はフィッティングパラメータである。Fig. 9 (c) 中の点線は, Eq. (2) で近似したす寸粒子径累積分布を 以下のすす粒子径分布に変換したものである。

$$
f\left(D_{p}\right)=\frac{1}{\sqrt{2 \pi} \sigma D_{p}} \exp \left[-\frac{\left\{\ln \left(D_{p}\right)-\mu\right\}^{2}}{2 \sigma^{2}}\right]
$$

Eq. (2)で得られたすす粒子径累積分布と TiRe-LII 計測で 得られた LII 信号強度減衰比から算出するすす粒子径累 積分布が一致するように，LII 信号強度隇衰比とすす粒 子径の関倸を示す関数を以下の式で定義した。

$$
D_{p}=k_{1} S^{k_{2}}+k_{3}
$$

ここで, $S$ は LII 信号強度比, $k_{1}, k_{2}, k_{3}$ はフィッティン グパラメータである。Table 3 に, Eq. (4) のフィッティン グ結果を示す。Fig. 10 に，TiRe-LII 計測で得られた LII 信号強度比の画像から, Eq. (4)により求めたバーナ中心 からの各半径方向位置におけるすす粒子径分布を示す。 各粒子径分布は，画像から得られる粒径分布を 500 枚分 から平均化したものである。

Fig. 10 (c) から, バーナ先端からの高さ $\mathrm{H}=35 \mathrm{~mm}$ に 比べ, $\mathrm{H}=95 \mathrm{~mm}$ のすす粒子径は増加している。これは, 滞留時間の増加に伴ってすすの凝集・成長が進んだため であると考えられる。Fig. 11 から，バーナ中心からの半 径方向距離 $\mathrm{R}=4 \sim 5 \mathrm{~mm}$ の位置にすすの体積分率のピー クが現れている。また，バーナ出口からの距離が短い $\mathrm{H}$ $=35 \mathrm{~mm}$ と比較して $\mathrm{H}=95 \mathrm{~mm}$ では, すすの体積分率が 増加するとともに，すすの存在する半径方向範囲が広が り，すす粒子径が大きくなっている。一方で，バーナ中 心からの半径方向距離に対するすす粒子径分布形状の差 異は小さい。その原因として, 本研究で用いている火炎 が乱流火炎であるため, 乱流混合によりすす粒子が生成 される場所が半径方向に広く分布している可能性が考え られる。

\section{6. 結 言}

基礎的な微粉炭ジェットバーナを対象として, 微粉炭 燃焼場に適した新たな計測手法を確立し，すす生成特性 の解明のためにその技術を応用した検討を行った。以下 に, それらの結果をまとめる。

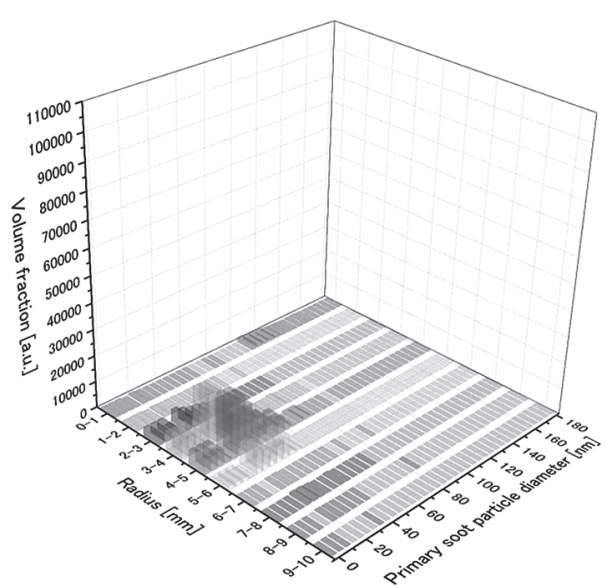

(a) $\mathrm{H}=35 \mathrm{~mm}$

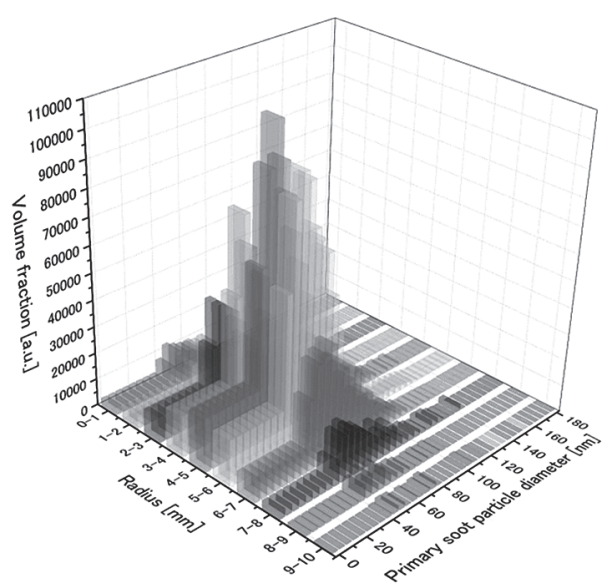

(b) $\mathrm{H}=95 \mathrm{~mm}$

Fig. 11 Particle-size distribution of soot obtained by TiRe-LII for radial direction [5]

・微粉炭とすすの熱容量の違いから微粉炭燃焼場にお けるすす体積分率の計測手法を新たに確立した。

・バーナ先端からの高さの増加に伴って, バーナ中心 軸付近の微粉炭粒子群にも高温の領域が現れる。高 温の領域では，揮発分の燃焼が行われることですす 体積分率も増加する。数值解析結果との比較によっ て, すす体積分率が高い箇所は温度が高く酸素濃度 が低いという結果が示された。

・す寸粒子径分布は, 半径方向にしたがって形状は変 化せず，下流方向にしたがってすすの成長・凝集で 粒子径が大きくなる。

以上の上うに, 微粉炭燃焼場においても光学計測を適 用することで，すすの挙動をある程度把握することが可 能となっている。しかしながら, より詳細に現象を解明 するためには, 素過程が影響をおよぼし合っている複雑 な場の状態を把握する必要があり, 関係する多くの物理 量を同時把握することは実験だけでは困難であると考え られる。そのため, 今後, 本研究のような詳細な実験と 多くの物理量を把握可能な数值解析が互いを補いながら 現象解明を進めていくことが重要であると考えられる。 


\section{References}

[1] S. M. Hwang, R. Kurose, F. Akamatsu, H. Tsuji, H. Makino, M. Katsuki, Observation of the detailed structure of turbulent pulverized coal flame by optical measurement (1st report, time-averaged measurement of behavior of the pulverized coal particles and the flame structure), Trans. Jpn. Soc. Mech. Eng. Ser. B, Japan 71 (2005) 2560-2567.

[2] S. M. Hwang, R. Kurose, F. Akamatsu, H. Tsuji, H. Makino, M. Katsuki, Observation of the detailed structure of turbulent pulverized coal flame by optical measurement (2nd report, instantaneous 2D-measurement of the combustion reaction zone and the pulverized coal particles), Trans. Jpn. Soc. Mech. Eng. Ser. B, Japan 71 (2005) 2754-2760.

[3] S. M. Hwang, R. Kurose, F. Akamatsu, H. Tsuji, H. Makino, M. Katsuki, Application of optical diagnostics techniques to a laboratory-scale turbulent pulverized coal flame, Energy Fuels 19 (2005) 382-392.

[4] J. Hayashi, N. Hashimoto, N. Nakatsuka, H. Tsuji, H. Watanabe, H. Makino, F. Akamatsu, Soot formation characteristics in a lab-scale turbulent pulverized coal flame with simultaneous planar measurements of laser induced incandescence of soot and Mie scattering of pulverized coal, Proc. Combust. Inst. 34 (2013) 2435-2443.

[5] N. Hashimoto, J. Hayashi, N. Nakatsuka, K. Tainaka, S. Umemoto, H. Tsuji, F. Akamatsu, H. Watanabe, H. Makino, Primary soot particle distributions in a combustion field of $4 \mathrm{~kW}$ pulverized coal jet burner measured by time resolved laser induced incandescence (TiRe-LII), J. Therm. Sci. Technol. 11-3 (2016) JTST0049.

[6] L. A. Melton, Soot diagnostics based on laser heating, Applied Optics 23 (1984) 2201-2208.

[7] B. Quay, T. W. Lee, T. Ni, R. J. Santoro, Spatially resolved measurements of soot volume fraction using laser-induced incandescence, Combust. Flame 97 (1994) 384-392.

[8] T. Ni, J. A. Pinson, S. Gupta, R. J. Santoro, Two-dimensional imaging of soot volume fraction by the use of laser-induced incandescence, Appl. Opt. 34 (1995) 7083-7091.

[9] C. S. Moreau, E. Therssen, X. Mercier, J. F. Pauwels, P. Desgroux, Two-color laser-induced incandescence and cavity ring-down spectroscopy for sensitive and quantitative imaging of soot and PAHs in flames, Appl. Phys. B 78 (2004) 485-492.

[10] L. L. McCrain, W. L. Roberts, Measurements of the soot volume field in laminar diffusion flames at elevated pressures, Combust. Flame 140 (2005) 60-69.

[11] M. D. Smooke, M. B. Long, B. C. Connelly, M. B. Colket, R. J. Hall, Combust. Flame 143 (2005) 613-628.

[12] N. H. Qamar, Z. T. Alwahabi, Q. N. Chan, G. J. Nathan, D. Roekaerts, K. D. King, Soot volume fraction in a piloted turbulent jet non-premixed flame of natural gas, Combust. Flame 156 (2009) 1339-1347.

[13] M. Nakamura, D. Nishioka, J. Hayashi, F. Akamatsu, Soot formation, spray characteristics, and structure of jet spray flames under high pressure, Combust. Flame 158 (2011) 1615-1629.

[14] J. Hayashi, H. Watanabe, R. Kurose, F. Akamatsu, Effects of fuel droplet size on soot formation in spray flames formed in a laminar counterflow, Combust. Flame 158 (2011) 25592568.

[15] J. Hayashi, J. Fukui, F. Akamatsu, Effects of droplet size distribution of fuel spray on soot formation in spray flames formed in a laminar counterflow, Proc. Combust. Inst. 34 (2013) 1561-1568.

[16] N. P. Tait, D. A. Greenhalgh, 2D soot field measurements by laser induced incandescence, Proc. Opt. Methods Data Process. Heat Transf. Fluid Flow Conf. England (1992) 185193.

[17] N. Hashimoto, R. Kurose, H. Shirai, Numerical simulation of pulverized coal jet flame employing the TDP model, Fuel 97 (2012) 277-287. 